\title{
Eoalosa janvieri gen. et sp. nov., a new clupeid fish (Teleostei, Clupeiformes) from the Eocene of Monte Bolca, Italy
}

\author{
Giuseppe Marramà ${ }^{1}$ (1) $\cdot$ Giorgio Carnevale ${ }^{2}$
}

Received: 10 December 2016/Accepted: 20 June 2017/Published online: 18 August 2017

(c) The Author(s) 2017. This article is an open access publication

\begin{abstract}
Fishes of the family Clupeidae are extremely abundant in the Eocene fossiliferous limestone of Monte Bolca representing the most common group from this celebrated locality. A new clupeid from the Pesciara site, Eoalosa janvieri gen. et sp. nov., is described. The new taxon exhibits a unique combination of characters supporting its recognition as a new genus and species of clupeid fish that is tentatively placed in the subfamily Alosinae. The description of this new taxon improves our knowledge of the diversity of clupeoid fishes in the Eocene of Monte Bolca.
\end{abstract}

Keywords Eoalosa janvieri gen. et sp. nov. - Clupeidae · Palaeobiodiversity $\cdot$ Konservat-Lagerstätte $\cdot$ Ypresian

Kurzfassung Fische aus der Familie der Clupeidae sind sehr häufig in den fossilführenden eozänen Schichten von Monte Bolca anzutreffen und repräsentieren die häufigste Knochenfischgruppe in dieser berühmten Fundstelle. Ein neuer Clupeide aus Monte Bolca, Eoalosa janvieri gen. et sp. nov., wird hier beschrieben und diskutiert. Dieses neue Taxon zeigt eine einzigartige Kombination von Merkmalen, welche die Aufstellung einer neuen Gattung und Art innerhalb der Unterfamilie Alosinae erlaubt. Die Beschreibung dieses neuen Heringsartigen trägt wesentlich

Handling editor: Adriana López-Arbarello.

Giuseppe Marramà

marramag81@univie.ac.at

1 Department of Palaeontology, University of Vienna, Geozentrum, Althanstraße 14, 1090 Vienna, Austria

2 Dipartimento di Scienze Della Terra, Università degli Studi di Torino, Via Valperga Caluso, 3510125 Turin, Italy zur Kenntnis der Diversität clupeoider Fische im Eozän von Monte Bolca bei.

Schlüsselwörter Eoalosa janvieri gen. et sp. nov. . Clupeidae · Paläobiodiversität · Konservat-Lagerstätte · Ypresium

\section{Introduction}

Fishes of the suborder Clupeoidei (herrings, sardines, shads, sprats, round herrings, and anchovies) represent one of the most abundant and widespread groups of teleosts. They currently comprise 91 genera and more than 400 extant species (Nelson et al. 2016) arranged in four families (Chirocentridae, Clupeidae, Engraulidae, Pristigasteridae), with a fossil record dating back to the Early Cretaceous (Figueiredo 2009). The suborder Clupeoidei includes small- to medium-sized fishes with a worldwide distribution from tropical to cold-temperate waters, where they form large schools that feed mainly on zooplankton (Whitehead 1985). Diagnostic characters of the Clupeoidei include, amongst others, the fusion of the first uroneural with the first preural centrum, a reduction in the relative size of the first ural centrum, an autogenous parhypural, loss of the lateral line scales, a single row of gill rakers on arches one to three, and second and third infraphryngobranchials that are reduced to long, narrow processes anteriorly (Grande 1985; Nelson et al. 2016). Fishes of the family Clupeidae differ from other clupeoids by having two long rod-like postcleithra in the pectoral girdle (Grande 1985). Clupeids have a moderately elongate and fusiform body, a mouth that is usually terminal (inferior in Dorosomatinae), teeth that are small or absent, a shortbased dorsal fin located at the midlength of the body, pelvic 
fins placed just in front of, below, or just behind the dorsalfin base, and a short anal fin that originates well behind the last dorsal-fin ray (Whitehead 1985).

The celebrated Eocene (ca. $50 \mathrm{Ma}$ ) Konservat-Lagerstätte of Monte Bolca is one of the most famous and wellstudied palaeontological sites in the world. It has yielded a huge amount of exquisitely preserved fishes that have provided clear evidence of the highly successful Early Palaeogene fish radiation in the aftermath of the extinction event at the end of the Cretaceous (Marramà et al. 2016a, b, c). More than 230 species (Carnevale et al. 2014)—-largely anguilliforms, aulopiforms, atheriniforms, beryciforms, clupeiforms, lophiiforms, pleuronectiforms, tetraodontiforms, and several other percomorph groups (e.g., Blot 1969, 1978; Blot and Tyler 1990; Tyler and Santini 2002; Bannikov 2004a, b, 2006, 2008; Monsch 2006; Bannikov and Carnevale 2009, 2010, 2016; Carnevale and Pietsch 2009, 2010, 2011, 2012; Marramà and Carnevale 2015a, b, 2016, 2017)—have been described to date. In particular, clupeiforms are represented by three clupeoid taxa: the sardine Bolcaichthys catopygopterus, the round herring Trollichthys bolcensis, and the engraulid Eoengraulis fasoloi. A recent taphonomic and quantitative palaeoecological study (Marramà et al. 2016a) revealed that the fish-bearing strata of the two productive sites of Monte Bolca, the Pesciara and Monte Postale, originated under different environmental conditions, and that the clupeid Bolcaichthys catopygopterus represents the most common taxon in the Pesciara fish assemblage in terms of number of specimens.

The aim of this work-another in a series of papers focused on the Eocene clupeoid fishes from Monte Bolca (see Marramà and Carnevale 2015a, b, 2016)—is to describe a new genus and species of clupeid fish based on a single specimen that was recently discovered in the palaeoichthyological collection of the Museum National d'Histoire Naturelle, Paris (MNHN).

\section{Materials and methods}

The present study is based on a unique well-preserved specimen with a preservation quality and slab lithology that clearly indicate it was collected at the Pesciara site. The specimen (MNHN F.Bol475) was examined using a Leica M80 stereomicroscope equipped with camera lucida drawing arm. Alcohol was used to enhance some details of the skeletal anatomy. Measurements were taken using a dial caliper to the nearest $0.1 \mathrm{~mm}$. The standard length (SL) is used throughout. Osteological terminology primarily follows Ridewood (1904), Phillips (1942), Grande (1985), and Marramà and Carnevale (2015a, b). Comparative information was derived mainly from the literature.

\section{Systematic palaeontology}

Superorder Clupeomorpha Greenwood, Rosen, Weitzman and Myers, 1966

Order Clupeiformes Bleeker, 1859

Suborder Clupeoidei Bleeker, 1859

Family Clupeidae Cuvier, 1817

Genus Eoalosa gen. nov.

Type species. Eoalosa janvieri sp. nov.

Etymology. The name is derived from the Greek word $\bar{E} \bar{o} s$ (meaning "dawn," "sunrise"), and the Latin word Alausa (meaning "shad").

Other species included. Type species only.

Diagnosis. Clupeid fish with elongated and tapered body, herring-like; SL about 3.5 times head length; mouth terminal; gape of the mouth extending posteriorly up to the anterior margin of the eye; two supramaxillae; strong and keeled abdominal scutes (12 prepelvic and at least 5 postpelvic) bearing thick ascending arms; at least 13 supraneurals; 47 vertebrae; 26 pleural ribs; pleural ribs to preural vertebrae ratio about 0.55 ; three epurals; dorsal fin small, inserting at about the mid-length of the body, containing about 15 rays; anal fin contains about 17 rays; pelvic-fin origin slightly behind the vertical through the origin of the dorsal fin; pelvic fin contains seven rays; scales perforated.

Remarks. The Alosinae, commonly known as shads, constitute an assemblage of temperate to tropical marine, estuarine, or freshwater fishes that include some of the largest clupeid species (Whitehead 1985). Traditionally, alosines include seven living genera (Alosa, Brevoortia, Ethmalosa, Ethmidium, Gudusia, Hilsa, and Tenualosa) and about 42 species (Nelson et al. 2016). However, only four genera (Alosa, Brevoortia, Sardinops, and Sardina) were recognized in this subfamily by Lavoué et al. (2014) based on molecular data. Caspialosa and Pomolobus, traditionally included within the alosines, are currently regarded as junior synonyms of Alosa (Whitehead 1985; Faria et al. 2006). Although the Alosinae, as well as other clupeid subfamilies, have long been considered 'groups of convenience' (Grande 1985) and were found to be nonmonophyletic in molecular studies (e.g., Lavoué et al. 2007, 2014), several authors recognized a set of morphological characters that were useful for separating alosines from other clupeid genera, including their large size (up to $60 \mathrm{~cm}$ in SL), the possession of strong and well-developed abdominal scutes, and the presence of a median notch between the two contralateral premaxillae, plus some features of the gill arches (e.g., basihyal cartilaginous, mediopharyngobranchial always present) and of the digestive tract (e.g., Nelson 1967; Whitehead 1973, 1985; 
Zaragüeta-Bagils 2001; Baykina and Schwarzhans 2017). As a consequence of this confused interpretative scenario, Eoalosa janvieri is tentatively referred herein to the Alosinae, based on a set of morphological characters observed in the examined specimen and discussed below (see "Discussion").

\section{Eoalosa janvieri sp. nov.}

Figures 1, 2, 3, 4, 5, 6, and 7 .

Etymology. Named in honour of the distinguished French palaeoichthyologist Philippe Janvier.

Holotype. MNHN F.Bol475, well-preserved, near-complete articulated skeleton on a single plate; $155.7 \mathrm{~mm}$ SL (Fig. 1).

Locality and horizon. Monte Bolca, Pesciara site, NE Italy; late Early Eocene, Late Ypresian, Middle Cuisian, slightly less than $50 \mathrm{Ma}$ (see Papazzoni et al. 2014).

Diagnosis. As for the genus.

Measurements (in mm; percentage of SL in parentheses). Head length: 43.7 (28.1); head depth: 26.1 (16.8); preorbital length: 12.3 (7.9); postorbital length: 17.1 (11.0); orbit diameter: 10.7 (6.9); maximum body depth: 41.2 (26.5); caudal peduncle length: 17.4 (11.2); caudal peduncle depth: 12.3 (7.9); predorsal length: 80.9 (52.0); preanal length: 125.1 (80.4); prepectoral length: 45.5 (29.2); prepelvic length: 88.9 (55.1); dorsal-fin base length: 17.5 (11.2); anal-fin base length: 14.9 (9.6).

\section{Description}

The body is elongate and laterally compressed, herring-like (Fig. 1); its greatest depth is about one-quarter the SL. The head is moderately elongate and triangular in outline; the $\mathrm{SL}$ is about 3.5 times the head length. The snout is pointed. The mouth is small and terminal. The belly is armored with strong and keeled prepelvic and postpelvic abdominal scutes bearing thick ascending arms compared to other clupeids. The dorsal-fin origin is located at about midlength of the body, whereas the pelvic fins insert slightly behind the vertical through the dorsal-fin origin. The body is completely covered with large and perforated cycloid scales.

Neurocranium. The neurocranium is elongate and nearly triangular in lateral outline (Fig. 2). The paired frontals are the largest bones of the skull roof, occupying about $60-70 \%$ of the neurocranial length. Each of the frontals articulates anteriorly with the mesethmoid, anteroventrally with the lateral ethmoid, and posteriorly with the parietal. Moreover, they articulate ventrally with the orbitosphenoid, and posteroventrally with the pterosphenoid. It is unclear if frontoparietal striae are present in the specimen examined. The parietal is a subrectangular bone that articulates anteriorly with the frontal, anteroventrally with the sphenotic, posterodorsally with the epioccipital, and posteroventrally with the pterotic. A small, ovoid temporal
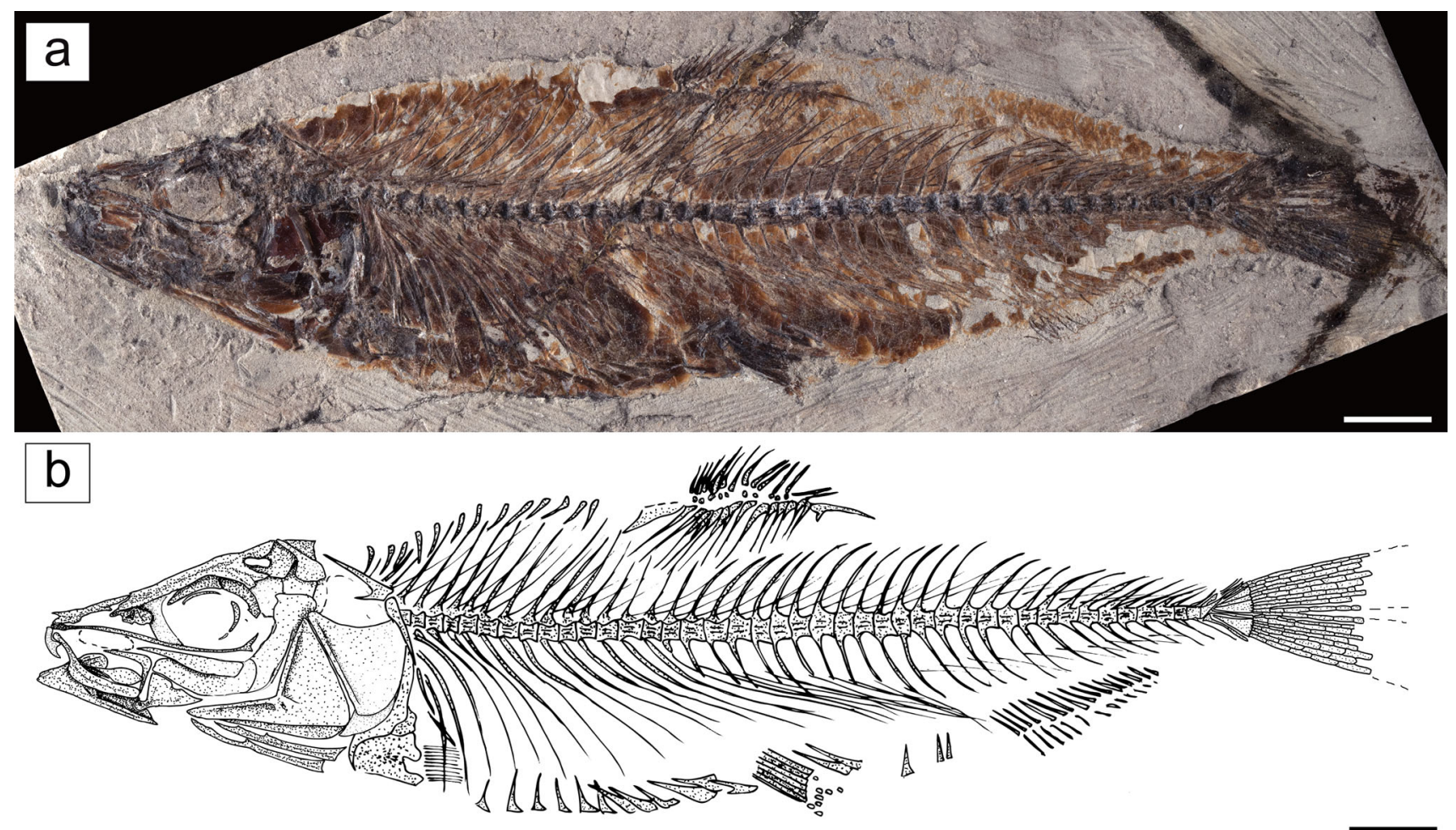

Fig. 1 Eoalosa janvieri gen. et sp. nov. a MNHN F.Bol475, holotype. b Reconstruction (scales omitted). Scale bars $10 \mathrm{~mm}$ 


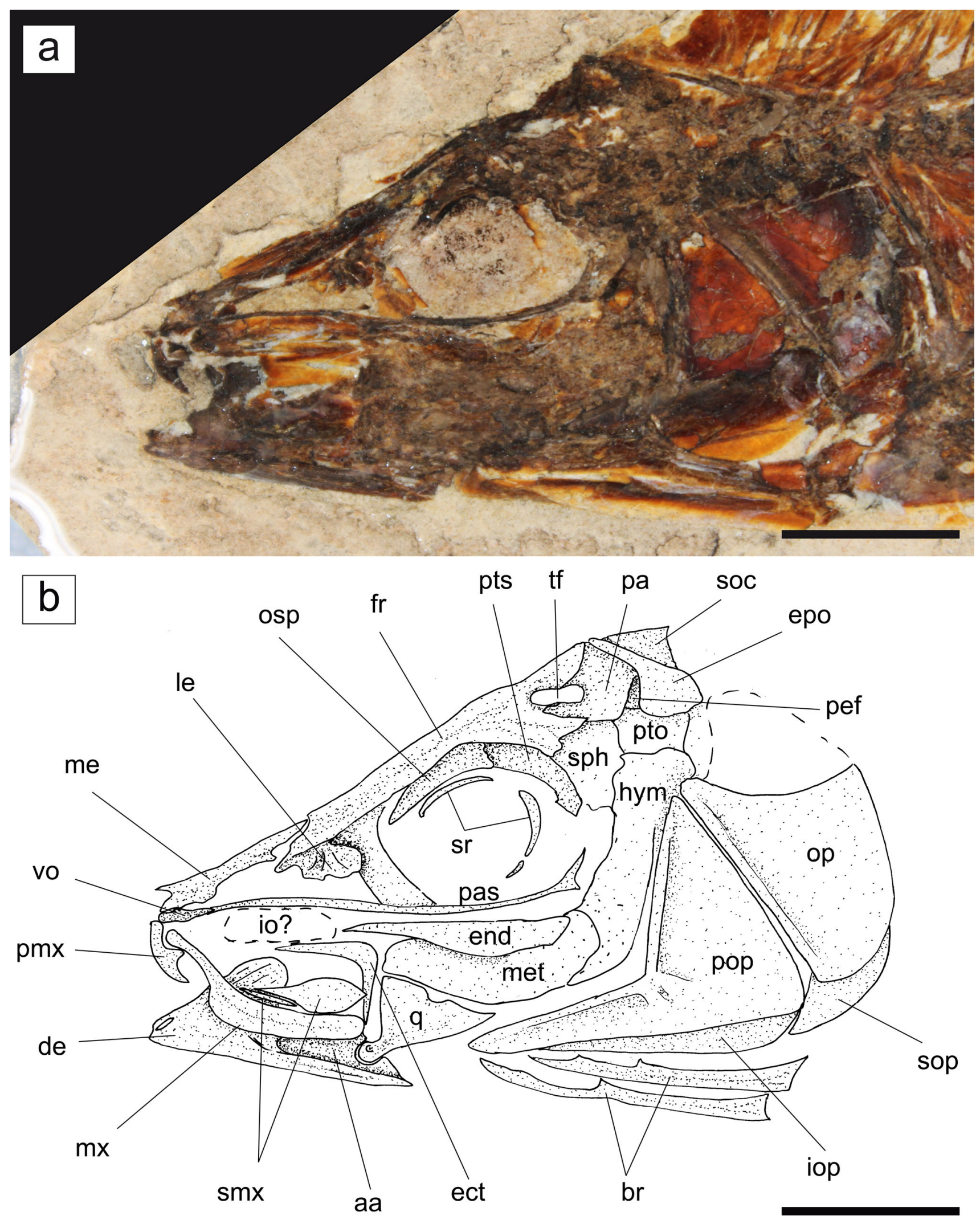


४Fig. 2 Eoalosa janvieri gen. et sp. nov.; MNHN F.Bol475, holotype. a Close-up of the head. b Reconstruction. Scale bars $10 \mathrm{~mm}$. Abbreviations: $a a$ anguloarticular, de dentary, ect ectopterygoid, end endopterygoid, epo epioccipital, fr frontal, hym hyomandibula, io? infraorbital, iop interopercle, le lateral ethmoid, me mesethmoid, met metapterygoid, $m x$ maxilla, op opercle, osp orbitosphenoid, $p a$ parietal, pas parasphenoid, pef pre-epiotic fossa, $p m x$ premaxilla, pop preopercle, pto pterotic, pts pterosphenoid, $q$ quadrate, smx supramaxilla, soc supraoccipital, sop subopercle, $s p h$ sphenotic, $s r$ sclerotic ring, if temporal foramen, vo vomer

foramen is demarcated by the posterior margin of the frontal and the anterior margin of the parietal. The preepiotic fossa is rather small. The supraoccipital crest is only partially preserved, and appears to be pointed and subtriangular in shape. The epioccipital articulates anteriorly with the parietal and posteriorly with the upper limb of the posttemporal. The otic region is badly preserved and cannot provide any information on its structure and configuration. The orbitosphenoid and pterosphenoid form the dorsal and posterior walls of the orbit, respectively. The basisphenoid is not clearly recognizable. The parasphenoid is very long, thin, and gently curved, extending for the most of the basicranial length. The vomer is short and apparently toothless. The mesethmoid is long, slender, and irregular in outline. The lateral ethmoid is expanded ventrally and bears a few striae along its outer surface.
Circumorbital series. The orbital cavity is large and rounded. The diameter of the orbit is similar to the preorbital length (about $7 \%$ of the SL), resembling the condition of Alosa cf. crassa (see Carnevale 2007). Except for the first infraorbital, the bones of the circumorbital series are insufficiently preserved in the available specimen. Two semicircular plates of the sclerotic ring are partially recognizable.

Jaws. The edentulous premaxilla is small, robust, and subtriangular in shape. Since the specimen is preserved in lateral view, it is not possible to fully describe the peculiar median notch between the two premaxillae typical of the Alosinae (Whitehead 1985) into which the symphysis of the lower jaw fits. The mouth gape of Eoalosa extends posteriorly close to the vertical from the anterior margin of the eye. The maxilla is elongate and laterally flattened, not reaching the anterior margin of the orbit; it is angled in the anterior one-third of its length, with a narrow anterior and an expanded posterior portion forming an angle of about $130^{\circ}$. The oral margin of the maxilla is slightly convex and appears to be edentulous. Eoalosa possesses two supramaxillae; the first is thin, straight, and rod-like, whereas the second is large and paddle-shaped. The dentary is robust, deep, and its general morphology is similar to that of Alosa (see Svetovidov 1964, fig. 8). The dentary appears to be edentulous and a small flattened ovoid foramen lies along
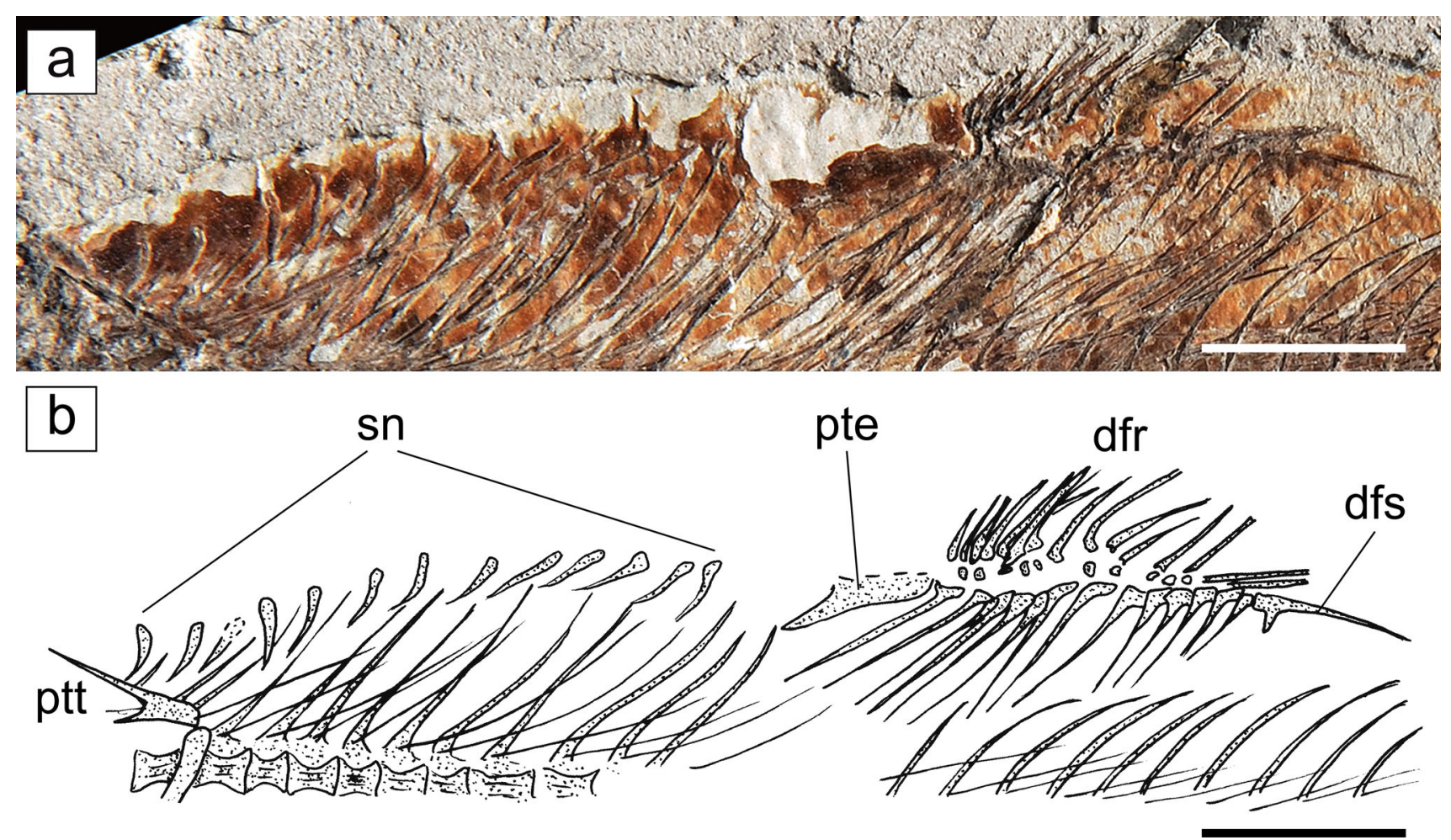

Fig. 3 Eoalosa janvieri gen. et sp. nov.; MNHN F.Bol475, holotype. a Detail of the anterodorsal margin of the body showing the supraneurals and the dorsal fin. b Reconstruction (scales omitted).
Scale bars $10 \mathrm{~mm}$. Abbreviations: $d f r$ dorsal-fin rays, $d f s$ dorsal-fin stay, pte first dorsal-fin pterygiophore, ptt posttemporal, sn supraneurals 


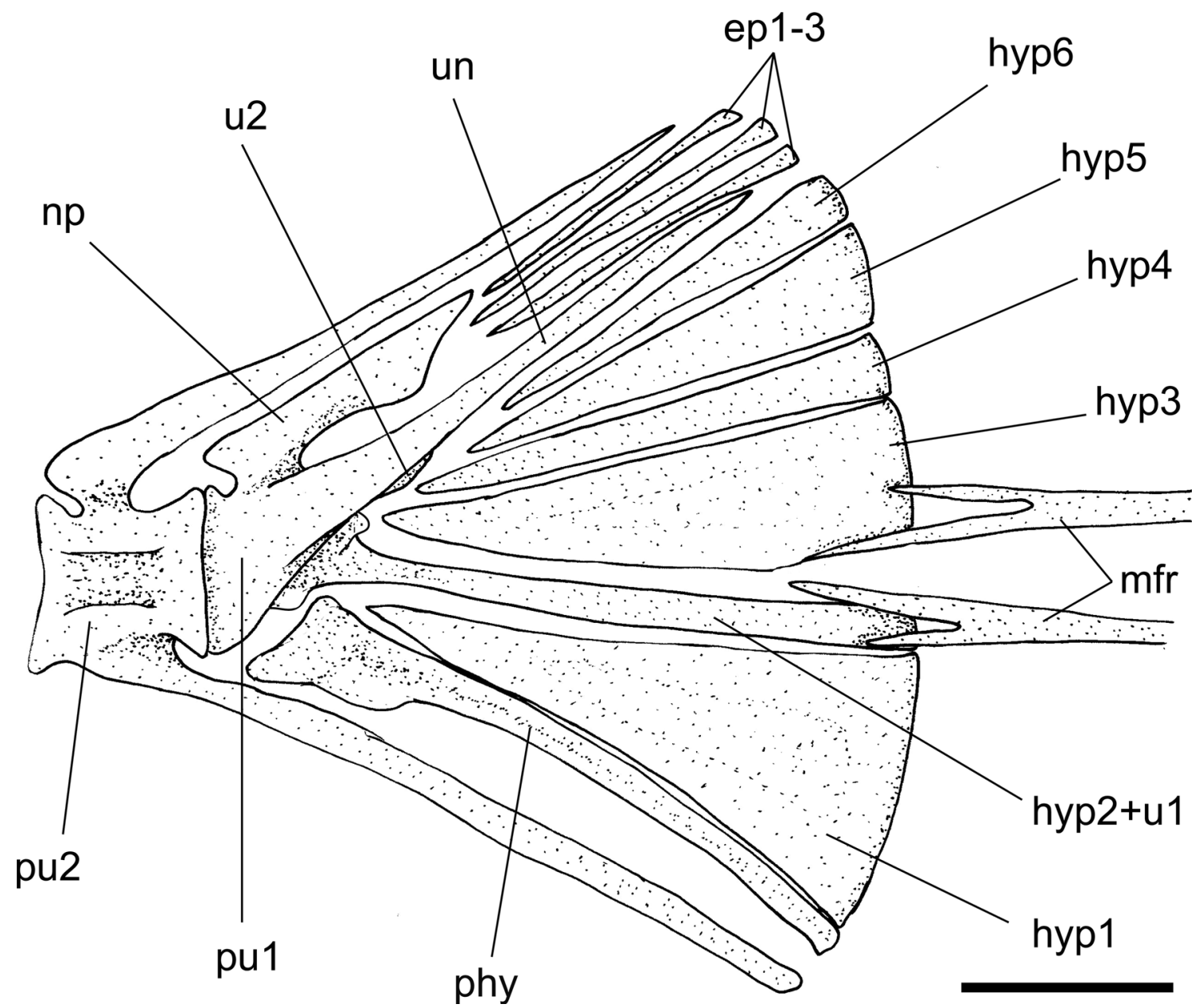

Fig. 4 Eoalosa janvieri gen. et sp. nov.; MNHN F.Bol475, holotype; reconstruction of the caudal skeleton. Scale bar 2 mm. Abbreviations: ep epural, hyp hypural, $m f r$ median caudal-fin rays, $n p$ neural plate, $p h y$ parhypural, $p u$ preural centrum, $u$ ural centrum, $u n$ uroneural

its anteroventral margin. The anguloarticular is robust but its morphology is not clearly recognizable.

Suspensorium. The palatine is not recognizable. The ectopterygoid is well developed, forming an angle of about $90^{\circ}$ between its dorsal (horizontal) and ventral portions. The endopterygoid is elongate and expanded posteriorly. The metapterygoid is subquadrangular in shape. The quadrate is triangular in shape, and its well-developed condyle of the quadrate-articular joint is located just below the anterior margin of the orbit. There is no trace of the large ovoid foramen between the quadrate and metapterygoid that is characteristic of certain species of Alosa (see Ridewood 1904), even if a small notch is visible along the dorsal margin of the quadrate. The hyomandibula is poorly preserved, but it clearly articulates ventrally with the metapterygoid (Fig. 2).

Opercular series and hyoid bar. The preopercle is large and crescent-shaped; its vertical arm is slightly shorter than the horizontal one. The number of branches of the preopercular sensory canal is impossible to define. The opercle is broad, with a gently rounded posterior margin and a straight anterior margin. Its surface is apparently smooth, without radiating striae or grooves. The subopercle is small and triangular in shape, whereas the interopercle is relatively long and slender. The hyoid bar and gill arches are not clearly recognizable. Two (or three?) long and robust branchiostegal rays are visible under the ventral arm of the preopercle (Fig. 2), but the precise number of them is difficult to discern. Small projections seem to be present dorsally on each branchiostegal. Since some clupeiforms possess projections ventrally on branchiostegal rays (McAllister 1968), we cannot exclude the possibility that their unusual position in Eoalosa might be due to preservation bias.

Vertebral column and intermuscular bones. The vertebral column consists of 47 preural vertebrae, including the urostylar element, of which 20 are abdominal and 27 caudal (Fig. 1). The vertebral centra are subquadrangular in shape with a slight constriction in the middle. Neural and 
Fig. 5 Eoalosa janvieri gen. et sp. nov.; MNHN F.Bol475, holotype; reconstruction of the pectoral girdle. Scale bar $5 \mathrm{~mm}$. Abbreviations: $\mathrm{cl}$ cleithrum, $c o$ coracoid, $p c l$ postcleithra, pec pectoral-fin rays, $p t t$ posttemporal, sca scapula, scl supracleithrum

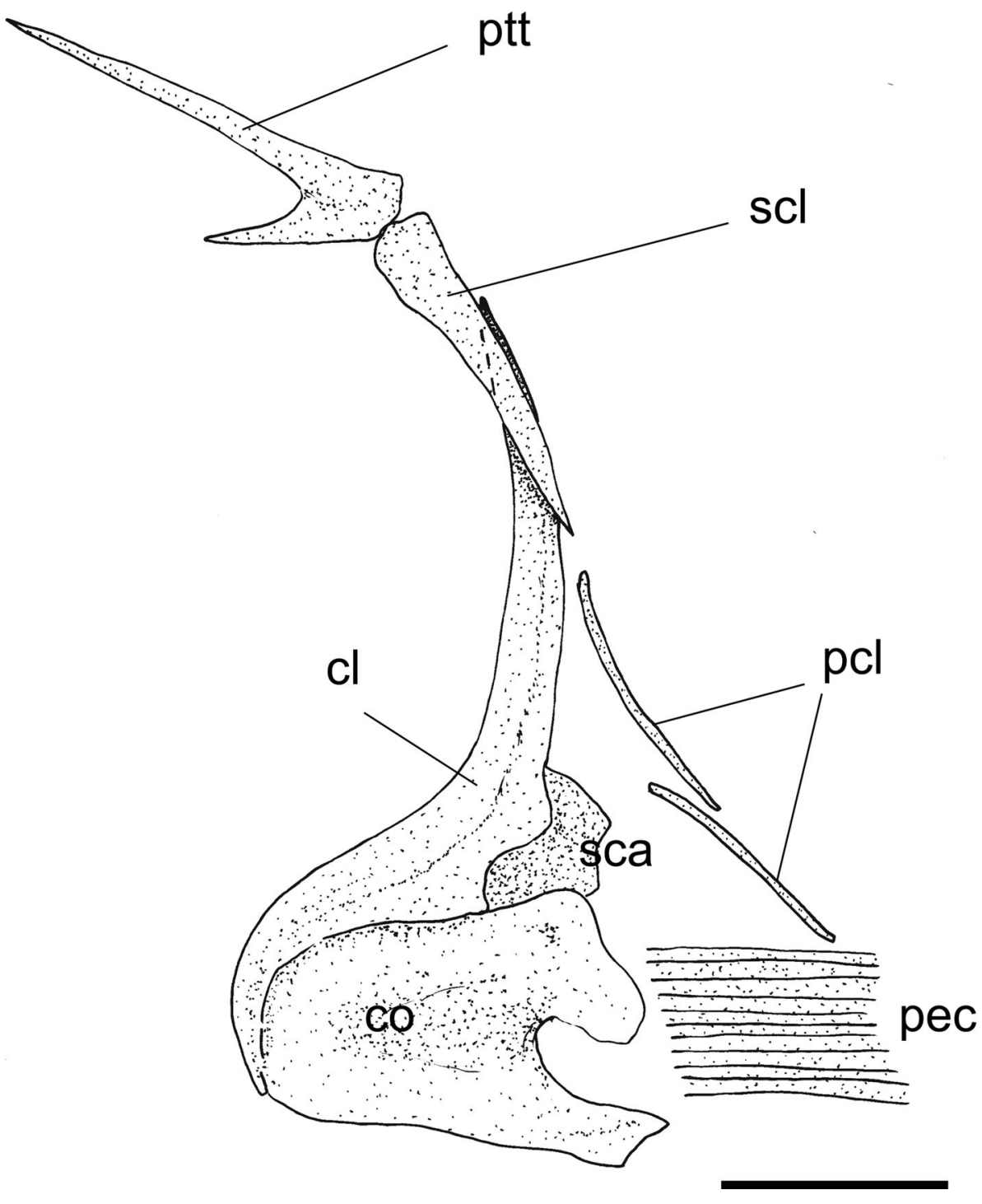

hemal arches are well developed throughout the entire length of the vertebral column. The neural prezygapophyses and the neural and hemal postzygapophyses are short, not expanded. 26 pairs of pleural ribs appear to be present, with the first rib articulating with the third vertebra; all ribs reach the ventral margin of the body. The ratio of the number of pleural ribs to the number of preural vertebrae (= pleural ribs-preural vertebrae ratio of Grande 1985) is 0.55 , thereby reflecting the relatively large size of the abdominal cavity, which is typical of representatives of the Clupeoidea (see Grande 1985). The epineurals are very long and thin, and extend posteriorly for most of the caudal region; they articulate with the base of the neural spines from the third or fourth vertebra to the 19th or 20th vertebrae, becoming short and free from articulation in the caudal region. Epipleurals and epicentrals are not clearly recognizable, although short epipleurals are visible in the caudal region. There are at least 13 slender and backward- inclined supraneurals, with a dorsal tip that reaches the dorsal border of the body (Fig. 3). However, the presence of a preservational gap in front of the dorsal fin suggests that more supraneurals would have been present.

Caudal skeleton. The structure of the caudal skeleton of Eoalosa (Fig. 4) is consistent with that of other clupeoid fishes (Grande 1985). The first preural centrum is short and subtriangular in shape; dorsally, it bears a laminar and trapezoidal neural plate. The first ural centrum is fused to the second hypural. The second ural centrum is small. There are six hypurals, all autogenous except for the second one, which is elongate, slender, and fused to the first ural centrum; the first hypural appears to be the largest of the series. The parhypural is autogenous and slender, characterized by an expanded proximal end. The first uroneural is long, rodlike, and fused with the first preural centrum. There is no clear evidence of other uroneurals. There are three slender, 

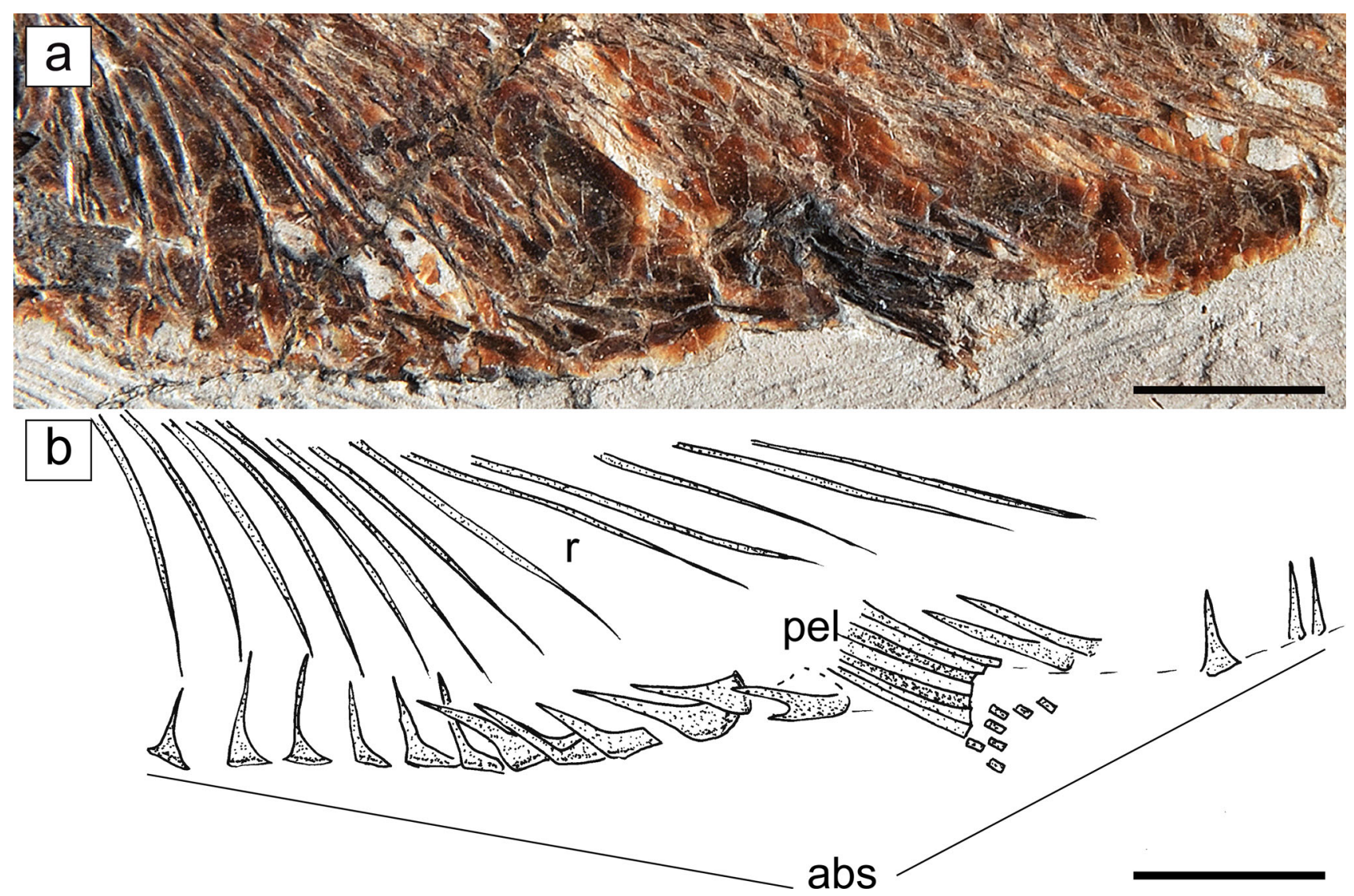

Fig. 6 Eoalosa janvieri gen. et sp. nov.; MNHN F.Bol475, holotype. a Detail of the abdominal region showing the abdominal scutes. b Reconstruction (scales omitted). Scale bars $10 \mathrm{~mm}$. Abbreviations: abs abdominal scutes, pel pelvic-fin rays, $r$ ribs

straight, and rod-like epurals. The caudal fin contains 19 or 20 principal caudal-fin rays, of which the central two bear a dorsal and a ventral peg, as in all alosines, most clupeines, and the pristigasterid Ilisha (Grande 1985). The procurrent rays are not clearly recognizable.

Median fins. The dorsal fin originates at about the midlength of the body, just above the 21st to 27th vertebrae; it is short-based and contains about 15 rays supported by an equal number of pterygiophores. There is a long dorsal-fin stay (sensu Weitzman 1962) (Fig. 3). The anal fin lies well behind the dorsal-fin base; it is short and might contain about 17 rays, based on the presence of an equal number of pterygiophores; the endoskeletal elements of the anal fin appear to be associated with the hemal spines of the 33rd to 38 th vertebrae. There are no separate finlets. The anal-fin stay is extremely short.

Paired fins and girdles. The pectoral girdle (Fig. 5) is consistent with those of other clupeid fishes (see Grande 1985). The posttemporal is long and bifurcated, with a thin and rod-like dorsal arm. The supracleithrum is long and slightly curved. The cleithrum is the largest element of the pectoral girdle. The coracoid is robust and triangular in outline with a convex anteroventral margin and a nearly concave posterior margin. There are two long and rod-like postcleithra. The scapula is partially hidden by the coracoid. The mesocoracoid and proximal radials are not clearly recognizable. The pectoral fin contains at least ten rays, but the original number of them is probably obfuscated by taphonomic processes. The pelvic fin originates slightly behind the dorsal-fin origin and contains seven distally segmented rays. Due to the thickness of the scales covering the abdominal region, the basipterygia are not clearly exposed and cannot be properly described.

Abdominal scutes. Eoalosa is characterized by a continuous series of abdominal scutes that extend from the isthmus to the anal-fin origin (Fig. 6). There are 12 prepelvic, one pelvic, and at least five postpelvic keeled scutes bearing thick ascending arms. The abdominal scutes are strong and well ossified, especially those located just in front of the pelvic fins. Considerably well-developed abdominal scutes are regarded as diagnostic of the alosines (e.g., Whitehead 1985; Baykina and Schwarzhans 2017; Nelson et al. 2016), although several other clupeoids show this character (e.g., 

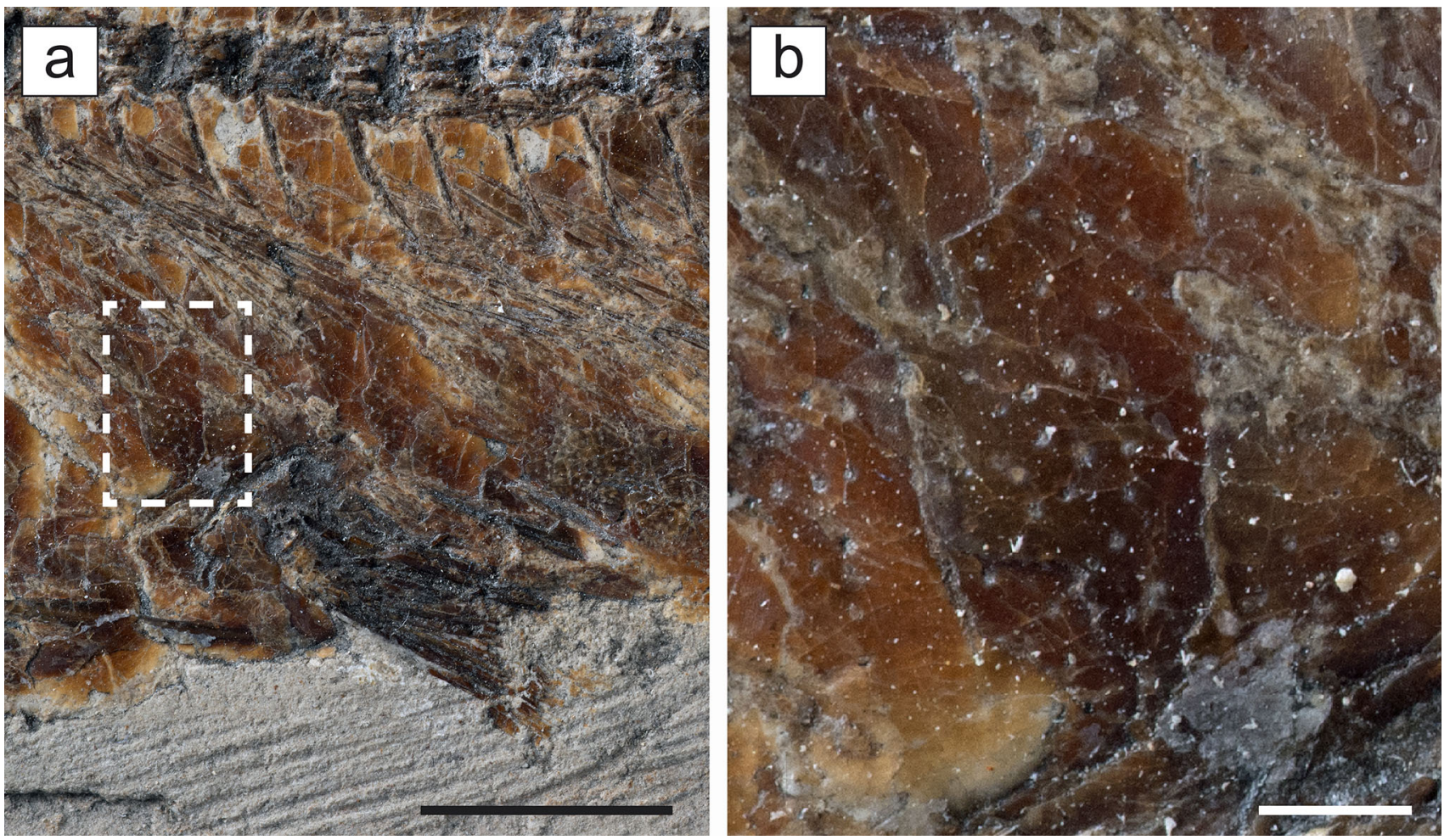

Fig. 7 Eoalosa janvieri gen. et sp. nov.; MNHN F.Bol475, holotype. a Close-up of the scales of the abdominal region, scale bar 10 mm. b Detail of the area indicated, scale bar $1 \mathrm{~mm}$

pristigasterids; see Grande 1985, fig. 11). There are no predorsal scutes.

Squamation. The entire body is covered by thick and large cycloid scales (Fig. 1a). The scales are deeply overlapping, well-attached, and arranged in about 30-40 transverse scale rows. The number of horizontal rows is difficult to define. The scales are subcircular in shape and highly perforated along their entire surface (Fig. 7), resembling the condition of certain alosines of the genera Alosa and Hilsa (e.g., Szymczyk 1978; Whitehead 1985; Munroe et al. 1999). However, in contrast to extant species, the perforations are present both in the anterior and posterior regions of the body. The posterior margin of the scales appears to be smooth. Vertical striae or circuli are not evident on the scales. Lateral line scales are absent.

\section{Discussion}

Descriptive analysis of the skeletal morphology of Eoalosa janvieri revealed the presence of several diagnostic characters that unquestionably support its inclusion within the Clupeomorpha, including one or more abdominal scutes crossing the ventral midline of the body, presence of the pre-epiotic fossa, second hypural fused with the first ural centrum, and an autogenous first hypural (Grande 1985). Because of the inadequate preservation of the otic region of the neurocranium, two additional remarkable clupeomorph synapomorphies (an otophysic connection that penetrates the exoccipital and forms ossified bullae in the prootic and usually also in the pterotic; a supratemporal commissural sensory canal that primitively passes through parietals) cannot be checked in the single available specimen described herein. The assignment of Eoalosa to the Clupeoidei is justified by the fusion of the first uroneural with the first preural centrum, the reduction of the first ural, the presence of an autogenous parhypural, and the absence of lateral-line scales (Grande 1985). The relatively high pleural rib to preural vertebrae ratio $(0.55)$ suggests that Eoalosa is a member of the superfamily Clupeoidea. The assignment to the family Clupeidae is clearly supported by the presence of two long, rod-like postcleithra (Grande 1985).

Grande (1985) and Whitehead (1985) recognized five subfamilies within the Clupeidae (Alosinae, Clupeinae, Dorosomatinae, Dussumieriinae, Pellonulinae), although recent molecular studies suggest that this family might be non-monophyletic (e.g., Lavoué et al. 2007, 2014; Li and Ortí 2007). Because of its unique combination of osteological and meristic features, Eoalosa cannot be 
confidently assigned to any of the previously described clupeid genera (see, e.g., Grande 1985; Whitehead 1985). Eoalosa exhibits a series of prepelvic and postpelvic scutes, thereby implying that it cannot be referred to the subfamily Dussumieriinae, whose representatives are characterized by an absence of prepelvic and postpelvic scutes and the presence of a single $\mathrm{W}$-shaped scute immediately anterior to the pelvic fins (Grande 1985; Whitehead 1985). Eoalosa cannot be placed within the subfamily Pellonulinae because the representatives of this group are characterized by a missing anterior supramaxilla and the fusion of the first ural centrum with the first preural centrum (Grande 1985). Although there is no unambiguous osteological evidence supporting the monophyletic status of the subfamilies Dorosomatinae, Clupeinae, and Alosinae, any assignment of Eoalosa to the Dorosomatinae can be ruled out because of the absence of the features that characterize the genera of this assemblage, including a dentary that is flared outwards, mouth inferior, a snout usually rounded and projecting, and a filamentous last dorsal-fin ray (Grande 1985; Whitehead 1985). Although the morphology of the gill arches may include some derived characters that are useful for separating the Clupeinae from the Alosinae (Nelson 1967; Grande 1985), the inadequate preservation of the gill skeleton does not allow the observation of these structures. According to several studies, the Alosinae can be distinguished from the Clupeinae by the presence of a medium to large or very large body (from 150 to $600 \mathrm{~mm}$ in SL), the presence of predorsal scutes (e.g., in Ethmidium, Ethmalosa, and some species of Alosa), an upper jaw frontally not rounded and characterized by a distinct notch into which the symphysis of the lower jaw fits, and the presence of a full range of highly developed abdominal scutes (Svetovidov 1963, 1964; Whitehead 1973, 1985; Baykina and Schwarzhans 2017). Moreover, certain alosines (e.g., Alosa cf. sagorensis and Hilsa) are characterized by body scales that are considerably perforated along their entire surface (Szymczyk 1978; Whitehead 1985; Munroe et al. 1999); clupeine genera usually do not exhibit this character, except for Sardinella, which possesses scales that are perforated only in the hind part (Whitehead 1985). Eoalosa reaches about $156 \mathrm{~mm}$ SL (it probably reached about $200 \mathrm{~mm}$ in total length), making it markedly larger than most Clupeinae. Eoalosa also possesses strong and welldeveloped prepelvic and postpelvic scutes and completely perforated body scales. Although some representatives of the Pristigasteridae also possess strong ventral scutes (see Grande 1985, fig. 11), we can exclude the possibility that Eoalosa belongs to this family because of an absence of typical pristigasteroid characters (e.g., supraneurals oriented either vertically or inclined anterodorsally, and missing interlobar notch in the third hypural; Grande
1985). For these reasons, Eoalosa is tentatively assigned herein to the subfamily Alosinae.

Eoalosa differs from the other alosine genera by having a unique combination of meristic features (Table 1). It can be easily separated from Brevoortia, Ethmalosa, Ethmidium, Gudusia, Hilsa, Moldavichthys, and Pugliaclupea based on its higher number of supraneurals (at least 13 vs. 6-12). Eoalosa lacks the dorsal scutes that are diagnostic of some species of Alosa (e.g., A. aestivalis), Ethmalosa, and Ethmidium. The number of preural vertebrae is useful for separating Eoalosa (47) from Ethmalosa, Gudusia, Hilsa, Moldavichthys, 'Pomolobus' and Tenualosa (39-45), Ethmidium (49), and possibly from Pugliaclupea (estimated to be 38-40). Moreover, Eoalosa has seven pelvic-fin rays, in contrast to Alosa, Moldavichthys, and 'Pomolobus' (8-11). It also possesses about 15 dorsal-fin pterygiophores, whereas Ethmalosa, Ethmidium, Hilsa, and Moldavichthys have 16-19 elements and Chasmoclupea has 12. Eoalosa also has about 17 anal-fin pterygiophores, compared with the 18-27 of Brevoortia, Ethmalosa, Gudusia, and Hilsa and the 12-15 of Ethmidium. Finally, the number of epurals can be used to separate Eoalosa (3) from Brevoortia, Ethmidium, Hilsa, Moldavichthys, and Pugliaclupea (1-2).

As discussed above, three clupeoid genera are known from Monte Bolca, including an engraulid (Eoengraulis) and two clupeids (Bolcaichthys and Trollichthys) (Marramà and Carnevale 2015a, b, 2016). E. janvieri is easily distinguishable from Eoengraulis fasoloi because of the lack of the diagnostic characters typical of anchovies, including the presence of a prominent snout with the mesethmoid projecting beyond the vomer, and an obliquely inclined suspensorium (Grande and Nelson 1985; Marramà and Carnevale 2016). Trollichthys bolcensis is considered the earliest unambiguous round herring (subfamily Dussumieriinae) due to the absence of prepelvic and postpelvic abdominal scutes and the presence of a unique $\mathrm{W}$-shaped pelvic scute (Marramà and Carnevale 2015a), characters which are absent in Eoalosa janvieri. The sardine Bolcaichthys catopygopterus is by far the most abundant clupeoid in the Eocene fish assemblage of Monte Bolca (Marramà and Carnevale 2015b; Marramà et al. 2016a). Eoalosa can be easily separated from this clupeine based on its larger size (the maximum SL for B. catopygopterus is about $10 \mathrm{~cm}$ ), much stronger and well-developed abdominal scutes, and different meristic counts.

The oldest fossil currently assigned to the Alosinae, Pugliaclupea nolardi from the Late Cretaceous (Campanian, ca. $74 \mathrm{Ma}$ ) of southern Italy (Taverne 2004), was created based on a single incomplete specimen lacking the caudal region. Subsequently, Taverne (2007) described an isolated incomplete caudal skeleton and referred it to the same taxon. Pugliaclupea was assigned to the Alosinae 


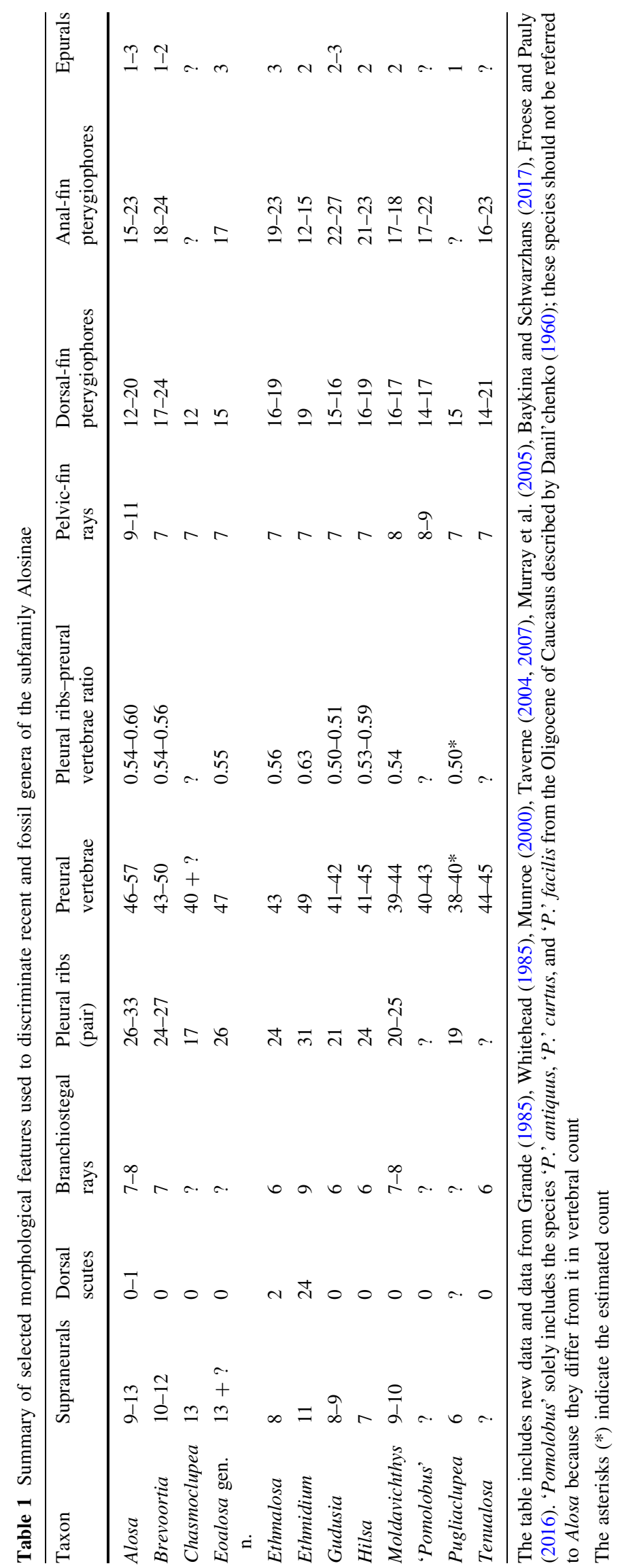


because of its overall similarity to the extant alosine genera. The evidence supporting the assignment of this Cretaceous clupeoid to the Alosinae appears to be weak, and new largely complete material would be necessary to demonstrate such a hypothesis. With the exception of Pugliaclupea nolardi, all the fossil species that have been referred to the Alosinae come from Cenozoic deposits (see Grande 1985). Following the common practice of most of the authors from the nineteenth and twentieth centuries, most of them have been referred to the basket genus Alosa (e.g., Sauvage 1873; Woodward 1901; Arambourg 1927; Rückert-Ülkümen 2006; but see Grande 1985 for a comprehensive list of the fossil species assigned to this genus), although taxonomic revisions would certainly demonstrate that they do not all belong to Alosa (Zaragüeta-Bagils 2001; Baykina and Schwarzhans 2017). Three species from Oligocene marine deposits of the Caucasus have been referred to 'Pomolobus' by Danil'chenko (1960), although this genus is currently considered a junior synonym of Alosa. Several diagnostic characters of the Alosinae are evident in the Oligocene species referred to 'Pomolobus,' but its meristic complement greatly differs from that of the genus Alosa (see Table 1), suggesting that additional comparative information would be desirable to conclusively demonstrate their separate generic status. Murray et al. (2005) described a clupeid fish from the Oligocene of Egypt (Chasmoclupea aegyptica) and concluded that it may be a member of either the Clupeinae or the Alosinae. The large body size of this fossil and the high and welldeveloped abdominal scutes support the hypothesis that Chasmoclupea can be aligned with the shads. According to Baykina (2015) 'Clupea' inflata from the Miocene of the Balkan Peninsula is likely a member of the Alosinae. The extinct genera Alisea, Ganoessus, Xyrinus, and Ganolytes from the Upper Miocene sediments of California (Jordan 1919, 1920, 1921; Jordan and Gilbert 1919) have been referred to the Clupeidae by several authors (e.g., David 1943; Grande 1985; Fierstine et al. 2012). Because of their large size (about 40-60 cm) and their well-developed abdominal scutes, they could tentatively be regarded as alosines; however, additional comparative information would be necessary to definitively verify this assumption. More recently, Baykina and Schwarzhans (2017) performed a revisionary analysis of 'Clupea humilis' from the Middle Miocene of Moldova and assigned it to a new genus and species (Moldavichthys switshenskae) of the Alosinae. Finally, a few species from the Pliocene of Russia have been referred to the extant genus Hilsa (see Gabelaya 1976), although their placement appears to be doubtful (Grande 1985).

\section{Conclusions}

The morphological analysis of the near-complete articulated skeleton documented herein has revealed the existence of a new clupeoid taxon in the Eocene limestone of the Pesciara site. The presence of a single specimen of Eoalosa janvieri at the Pesciara site is not surprising. Several teleost taxa from Bolca, including the anchovy Eoengraulis fasoloi (see Marramà and Carnevale 2016), are represented by a unique known specimen, suggesting that they were adventitious visitors of the Bolca palaeobiotopes. The presence of engraulids, dussumieriines, clupeines, and possibly alosines in the Eocene deposits of Monte Bolca provides evidence of the heterogeneity of clupeid fishes in this celebrated fossil-Lagerstätte, which reflects the outstanding diversity of the entire ichthyofauna (see Carnevale et al. 2014). Because of their abundance, clupeid fishes certainly played an important ecological role in the Pesciara palaeobiotope (Marramà et al. 2016a), which was located in a palaeoenvironmental context close to the coast, and subject to the influence of the open sea (Landini and Sorbini 1996; Marramà et al. 2016a).

Acknowledgements Open access funding provided by University of Vienna. The authors thank Gaël Clément (MNHN) for permission to examine the fossil material under his care and logistic support. Thanks are also due to Philippe Loubry and Lilian Cazes (MNHN) for some of the photographs of the fossil specimen. The manuscript was improved by constructive reviews provided by Alison M. Murray (Department of Biological Sciences, University of Alberta) and Norbert Micklich (Hessisches Landesmuseum Darmstadt) as well as editorial comments from Adriana López-Arbarello and Mike Reich (Munich). We also thank Jürgen Kriwet (Department of Palaeontology, University of Vienna) for improving the German abstract. The research was supported by a Synthesys grant (FR-TAF-5419 to G.M.), by the Austrian Federal Ministry of Science, Research and Economy (Ernst Mach Grant ICM-2016-03318 to G.M.), and by grants (ex-60\% 2015 and 2016 to G.C.) from the Università degli Studi di Torino.

Open Access This article is distributed under the terms of the Creative Commons Attribution 4.0 International License (http://crea tivecommons.org/licenses/by/4.0/), which permits unrestricted use, distribution, and reproduction in any medium, provided you give appropriate credit to the original author(s) and the source, provide a link to the Creative Commons license, and indicate if changes were made.

\section{References}

Arambourg, C. 1927. Les poissons fossiles d'Oran. Matériaux pour la carte géologique de l'Algérie 6: 5-299.

Bannikov, A.F. 2004a. Eocottidae, a new family of perciform fishes (Teleostei) from the Eocene of northern Italy (Bolca). Studi $e$ Ricerche sui Giacimenti Terziari di Bolca 10: 17-35. 
Bannikov, A.F. 2004b. Fishes from the Eocene of Bolca, northern Italy, previously classified with the Chaetodontidae (Perciformes). Studi e Ricerche sui Giacimenti Terziari di Bolca 10: $55-74$.

Bannikov, A.F. 2006. Fishes from the Eocene of Bolca, northern Italy, previously classified in the Sparidae, Serranidae and Haemulidae (Perciformes). Geodiversitas 28: 249-275.

Bannikov, A.F. 2008. Revision of the atheriniform fish genera Rhamphognathus Agassiz and Mesogaster Agassiz (Teleostei) from the Eocene of Bolca, northern Italy. Studi e Ricerche sui Giacimenti Terziari di Bolca 9: 65-76.

Bannikov, A.F., and G. Carnevale. 2009. A new percoid fish from the Eocene of Monte Bolca, Italy: Hendrixella grandei gen. \& sp. nov. Swiss Journal of Geosciences 102: 481-488.

Bannikov, A.F., and G. Carnevale. 2010. Bellwoodilabrus landinii, a new genus and species of labrid fish (Teleostei: Perciformes) from the Eocene of Monte Bolca. Geodiversitas 32: 201-220.

Bannikov, A.F., and G. Carnevale. 2016. †Carlomonnius quasigobius gen. et sp. nov.: the first gobioid fish from the Eocene of Monte Bolca, Italy. Bulletin of Geosciences 91: 13-22.

Baykina, E.M. 2015. A new species of the genus Sardina (Pisces, Clupeidae) from the Middle Miocene of the Eastern Paratethys. Paleontological Journal 49: 402-406.

Baykina, E.M., and W.W. Schwarzhans. 2017. Review of "Clupea humilis" from the Sarmatian of Moldova and description of Moldavichthys switshenskae gen. et sp. nov. Swiss Journal of Palaeontology 136: 141-149.

Bleeker, P. 1859. Enumeratio specierum piscium hucusque in Archipelago indico observatarum, adjectis habitationibus citationibusque, ubi descriptiones earum recentiores reperiuntur, nec non speciebus Musei Bleekeriani Bengalensibus, Japonicis, Capensibus Tasmanicisque. Acta Societatis Regiae Scientiarum Indo-Neêrlandicae $[=$ Verhandelingen der Natuurkundige Vereeniging in Nederlandsch Indië] 6: xxxvi + 1-276.

Blot, J. 1969. Les poissons fossiles du Monte Bolca classés jusqu'ici dans les familles des Carangidae, Menidae, Ephippidae, Scatophagidae. Studi e Ricerche sui Giacimenti Terziari di Bolca 2: 1-522.

Blot, J. 1978. Les apodes fossiles du Monte Bolca. I. Studi e Ricerche sui Giacimenti Terziari di Bolca 3: 1-213.

Blot, J., and J.C. Tyler. 1990. New genera and species of fossil surgeon fishes and their relatives (Acanthuroidei, Teleostei) from the Eocene of Monte Bolca, Italy, with application of the Blot formula to both fossil and Recent forms. Studi e Ricerche sui Giacimenti Terziari di Bolca 6: 13-92.

Carnevale, G. 2007. Fossil fishes from the Serravallian (Middle Miocene) of Torricella Peligna, Italy. Palaeontographia Italica 91: 1-67.

Carnevale, G., A.F. Bannikov, G. Marramà, J.C. Tyler, and R. Zorzin. 2014. The Pesciara-Monte Postale Fossil-Lagerstätte: 2. Fishes and other vertebrates. In The Bolca Fossil-Lagerstätte: A window into the Eocene world, eds. C.A. Papazzoni, L. Giusbert, G. Carnevale, G. Roghi, D. Bassi, and R. Zorzin. Rendiconti della Società Paleontologica Italiana 4: 37-63.

Carnevale, G., and T.W. Pietsch. 2009. An Eocene frogfish from Monte Bolca, Italy: the earliest skeletal record for the family. Palaeontology 52: 745-752.

Carnevale, G., and T.W. Pietsch. 2010. Eocene handfishes from Monte Bolca, with description of a new genus and species, and a phylogeny of the family Brachionichthyidae (Teleostei: Lophiiformes). Zoological Journal of the Linnean Society 160: 621-647.

Carnevale, G., and T.W. Pietsch. 2011. Batfishes from the Eocene of Monte Bolca. Geological Magazine 148: 461-472.

Carnevale, G., and T.W. Pietsch. 2012. †Caruso, a new genus of anglerfishes from the Eocene of Monte Bolca, Italy, with a comparative osteology and phylogeny of the teleost family Lophiidae. Journal of Systematic Palaeontology 10: 47-72.

Cuvier, G. 1817. Le Règne Animal distribué d'après son organisation pour servir de base a l'histoire naturelle des animaux et d'introduction a l'anatomie comparée. Les reptiles, les poissons, les mollusques et les annelids, vol. 2. Paris: A. Belin.

Danil'chenko, P.G. 1960. Bony fishes of the Maikop deposits of the Caucasus. Akademiya Nauk SSSR. Trudy Paleontologicheskogo Instituta 78: 1-247. (in Russian).

David, L.R. 1943. Miocene fishes of southern California. Geological Society of America 43: 1-193.

Faria, R., S. Weiss, and P. Alexandrino. 2006. A molecular phylogenetic perspective on the evolutionary history of Alosa spp. (Clupeidae). Molecular Phylogenetics and Evolution 40: 298-304.

Figueiredo, F.J. 2009. A new marine clupeoid fish from the Lower Cretaceous of the Sergipe-Alagoas Basin, northeastern Brazil. Zootaxa 2164: 21-32.

Fierstine, H.L., R.W. Huddleston, and G.T. Takeuchi. 2012. Catalog of the Neogene bony fishes of California: A systematic inventory of all published accounts. Lawrence: Allen Press.

Froese, R., and D. Pauly. 2016. FishBase. http://fishbase.org. Accessed November 2016.

Gabelaya, T.D. 1976. Fish of the Pliocene deposits of Georgia. Tiflis: Metsniyereba. (in Russian).

Grande, L. 1985. Recent and fossil clupeomorph fishes with materials for revision of the subgroups of clupeoids. Bulletin of the American Museum of Natural History 181: 231-372.

Grande, L., and G. Nelson. 1985. Interrelationships of fossil and recent anchovies (Teleostei: Engrauloidea) and description of a new species from the Miocene of Cyprus. American Museum Novitates 2826: 1-16.

Greenwood, P.H., D.E. Rosen, S.H. Weitzman, and G.S. Myers. 1966. Phyletic studies of teleostean fishes, with a provisional classification of living forms. Bulletin of the American Museum of Natural History 131: 339-456.

Jordan, D.S. 1919. Fossil fishes of southern California. I. Fossil fishes of the Soledad deposits. Stanford: Leland Stanford Junior University Publications.

Jordan, D.S. 1920. The genera of fishes, pt. 4, from 1881 to 1920, thirty-nine years, with the accepted type of each. A contribution to the stability of scientific nomenclature. Stanford: Leland Stanford Junior University Publications.

Jordan, D.S. 1921. The fish fauna of the California Tertiary. Stanford: Leland Stanford Junior University Publications.

Jordan, D.S., and J.Z. Gilbert. 1919. Fossil fishes of southern California. 2. Fossil fishes of the Miocene (Monterey) formations of southern California. Stanford: Leland Stanford Junior University Publications.

Landini, W., and L. Sorbini. 1996. Ecological and trophic relationships of Eocene Monte Bolca (Pesciara) fish fauna. Bollettino della Società Paleontologica Italiana 3: 105-112.

Lavoué, S., P. Konstantinidis, and W.J. Chen. 2014. Progress in clupeiform systematics. In Biology and ecology of sardines and anchovies, ed. K. Ganias, 3-42. Boca Raton: CRC Press.

Lavoué, S., M. Miya, K. Saitoh, N.B. Ishiguro, and M. Nishida. 2007. Phylogenetic relationships among anchovies, sardines, herrings and their relatives (Clupeiformes), inferred from whole mitogenome sequences. Molecular Phylogenetics and Evolution 43: 1096-1105.

Li, C., and G. Ortí. 2007. Molecular phylogeny of Clupeiformes (Actinopterygii) inferred from nuclear and mitochondrial DNA sequences. Molecular Phylogenetics and Evolution 44: 386-398.

Marramà, G., A.F. Bannikov, J.C. Tyler, R. Zorzin, and G. Carnevale. 2016a. Controlled excavations in the Pesciara and Monte Postale sites provide new insights about the paleoecology and 
taphonomy of the fish assemblages of the Eocene Bolca Konservat-Lagerstätte, Italy. Palaeogeography, Palaeoclimatology, Palaeoecology 454: 228-245.

Marramà, G., and G. Carnevale. 2015a. Eocene round herring from Monte Bolca, Italy. Acta Palaeontologica Polonica 60: 701-710.

Marramà, G., and G. Carnevale. 2015b. The Eocene sardine † Bolcaichthys catopygopterus (Woodward, 1901) from Monte Bolca, Italy: osteology, taxonomy and paleobiology. Journal of Vertebrate Paleontology. doi:10.1080/02724634.2015.1014490.

Marramà, G., and G. Carnevale. 2016. An Eocene anchovy from Monte Bolca, Italy: The earliest known record for the family Engraulidae. Geological Magazine 153: 84-94.

Marramà, G., and G. Carnevale. 2017. Morphology, relationships and paleobiology of the Eocene barracudina †Holosteus esocinus (Aulopiformes, Paralepididae) from Monte Bolca, Italy. Zoological Journal of the Linnean Society. doi:10.1093/zoolinnean/ zlw029.

Marramà, G., C. Garbelli, and G. Carnevale. 2016b. A morphospace for the Eocene fish assemblage of Bolca, Italy: A window into the diversification and ecological rise to dominance of modern tropical marine fishes. Bollettino della Società Paleontologica Italiana 55: 11-21.

Marramà, G., C. Garbelli, and G. Carnevale. 2016c. A clade-level morphospace for the Eocene fishes of Bolca: Patterns and relationships with modern tropical shallow marine assemblages. Bollettino della Società Paleontologica Italiana 55: 139-156.

McAllister, D.E. 1968. The evolution of branchiostegals and associated opercular, gular, and hyoid bones, and the classification of teleostome fishes, living and fossil. Ottawa: Queen's Printer.

Monsch, K.A. 2006. A revision of scombrid fishes (Scombroidei, Perciformes) from the middle Eocene of Monte Bolca, Italy. Palaeontology 49: 873-888.

Munroe, T.A. 2000. An overview of the biology, ecology, and fisheries of the clupeoid fishes occurring in the Gulf of Maine. Northeast Fisheries Science Center Reference Document 00-02: $1-226$.

Munroe, T.A., T. Wongratana, and M.S. Nizinski. 1999. Clupeidae. In The living marine resources of the Western Central Pacific, FAO species identification guide for fishery purposes, eds. K.E. Carpenter, and V.H. Niem, 1775-1821. Rome: FAO.

Murray, A.M., E.L. Simons, and Y.S. Attia. 2005. A new clupeid fish (Clupeomorpha) from the Oligocene of Fayum, Egypt, with notes on some other fossil clupeomorphs. Journal of Vertebrate Paleontology 25: 300-308.

Nelson, G.J. 1967. Gill arches of teleostean fishes of the family Clupeidae. Copeia 2: 389-399.

Nelson, J.S., T.C. Grande, and M.V.H. Wilson. 2016. Fishes of the world, 5th ed. Hoboken: John Wiley \& Sons.

Papazzoni, C.A., G. Carnevale, E. Fornaciari, L. Giusberti, and E. Trevisani. 2014. The Pesciara-Monte Postale Fossil-Lagerstätte: 1. Biostratigraphy, sedimentology and depositional model. In The Bolca Fossil-Lagerstätte: A window into the Eocene world, eds. C.A. Papazzoni, L. Giusbert, G. Carnevale, G. Roghi, D. Bassi, and R. Zorzin. Rendiconti della Società Paleontologica Italiana 4: 29-36.
Phillips, J.B. 1942. Osteology of the sardine (Sardinops caerulea). Journal of Morphology 70: 463-500.

Ridewood, W.G. 1904. On the cranial osteology of the clupeoid fishes. Proceedings of the Zoological Society of London 2: 448-493.

Rückert-Ülkümen, N. 2006. Description of the new taxon Alosa megalosoma n. sp., extended description of Alosa brevicauda nov. nom. and Scorpaena acanthophora and associated fauna of the Sarmatian of Pinarhisar/Thrace (Turkey). Instanbul Yerbilimleri Dergisi 19: 63-76.

Sauvage, H.E. 1873. Mémoire sur la faune ichthyologique de la période tertiare, et plus spécialement sur les poissons fossils d'Oran (Algerie) et sur ceux découverts par M.R. Alby à Licata en Sicile. Annales de Sciences géologiques 4: 1-272.

Svetovidov, A.N. 1963. Clupeidae. In Fauna of the U.S.S.R. Fishes, eds. E.N. Pavlovskii, and A.A. Shtakel'berg, 1-428. Jerusalem: Israel Program for Scientific Translations.

Svetovidov, A.N. 1964. Systematics of the North American anadromous clupeoid fishes of the genera Alosa, Caspialosa, and Pomolobus. Copeia 1964: 118-130.

Szymczyk, W. 1978. Clupeid scales from the Menilite beds (Palaeogene) of the Carpathians. Acta Palaeontologica Polonica 23: 387-409.

Taverne, L. 2004. Les poissons crétacés de Nardò. $18^{\circ}$. Pugliaclupea nolardi gen. et sp. nov. (Teleostei, Clupeiformes, Clupeidae). Bollettino del Museo Civico di Storia Naturale di Verona 28: $17-28$.

Taverne, L. 2007. Les poissons crétacés de Nardò. $26^{\circ}$. Un second Dussumieriinae: Portoselvaggioclupea whiteheadi gen. et sp. nov. et complément à l'étude de Pugliaclupea nolardi (Teleostei, Clupeidae). Bollettino del Museo Civico di Storia Naturale di Verona 31: 37-42.

Tyler, J.C., and F. Santini. 2002. Review and reconstructions of the tetraodontiform fishes from the Eocene of Monte Bolca, Italy, with comments on related Tertiary taxa. Studi e Ricerche sui giacimenti Terziari di Bolca 9: 47-120.

Weitzman, S.H. 1962. The osteology of Brycon meeki, a generalized characid fish, with an osteological definition of the family. Stanford Ichthyological Bulletin 8: 1-77.

Whitehead, P.J.P. 1973. Clupeoid fishes of the Guianas. Bulletin of the British Museum (Natural History) Zoology, Supplement 5: $1-227$.

Whitehead, P.J.P. 1985. Clupeoid fishes of the world. (Suborder Clupeoidei). Part. 1. Chirocentridae, Clupeidae and Pristigasteridae. FAO Species Catalogue 7: 1-303.

Woodward, A.S. 1901. Catalogue of fossil fishes in the British Museum (natural history), 4: Containing the actinopterygian Teleostomi of the suborders Isospondyli (in part), Ostariophysi, Apodes, Percesoces, Hemibranchii, Acanthopterygii and Anacanthini. London: Taylor and Francis.

Zaragüeta-Bagils, R. 2001. Les Alosa fossiles et la notion de genre en systématique phylogénétique. Bulletin Français de la Pêche et de la Pisciculture 362-363: 1059-1066. 